\title{
Meningkatkan Kompetensi Guru Kelas dalam Penyusunan Rencana Pelaksanaan Pembelajaran (RPP) Kurikulum 2013 melalui Pendampingan Berbasis KKG di SDN Dondak Kec. Pujut Tahun pelajaran 2018/2019"
}

\author{
Wirentanus \\ Kepala SDN Dondak Kecamatan Pujut Lombok Tengah
}

\begin{abstract}
Abstrak. Penelitian ini berjudul "Upaya Meningkatkan Kompetensi Guru Kelas dalam penyusunan Rencana Pelaksanaan Pembelajaran (RPP) Kurikulum 2013 Melalui Pendampingan Berbasis KKG di SDN Dondak Semester Dua Tahun pelajaran 2018/2019" Latar belakang diadakannya Penelitian ini adalah rendahnya kompetensi guru sasaran di SDN Dondak dalam penyusunan RPP (Rencana Pelakssanaan Pembelajaran ) kurikulum 2013 yang berdampak kurang percaya diri dalam proses pembelajaran. Solusinya diadakan pendampingan baik secara kelompok maupun individu dalam penyusunan RPP Kurikulum 2013. Tujuannya adalah untuk mengetahui efektifitas pelaksanaan pendampingan berbasis KKG dalam upaya meningkatkan kompetensi guru dalam menyusun RPP kurikulum 2013, yang bermanfaat untuk meningkatkan profesionalisme sebagai kepala sekolah dan bagi guru untuk meningkatkan proses pembelajaran di kelas. Hipotesis tindakan: meningkatkan kompetensi guru kelas SDN Dondak Semester Dua tahun pelajaran 2018/2019 dalam menyusun RPP Renncana Pelaksanaan Pembelajaran (RPP) kurikulum 2013. Penelitian ini dilaksanakan sebanyak dua siklus, masing-masing siklus dua kali pertemuan. Tahapan setiap siklus adalah perencanaan, pelaksanaan, pengamatan, dan refleksi. Indikator keberhasilan dalam penelitian ini adalah; 1) hasil observasi Kepala Sekolah maupun observasi guru selama proses pendampingan telah memperoleh skor rata-rata $\geq 4,0,2$ ) hasil kerja guru dalam penyusunan RPP mencapai $\geq 100 \%$ dengan nilai rata-rata $\geq 70,00$. Hasil penelitian pada siklus I observasi Kepala Sekolah rata-rata $(3,40)$, observasi guru rata-rata $(3,33)$ dan hasil kerja individual rata-rata nilai $(67,33)$ dengan prosentase ketercapaian $(0 \%)$. Pada siklus II observasi Kepala Sekolah rata-rata $(4,40)$, observasi guru rata-rata $(4,50)$ dan hasil kerja individual rata-rata nilai $(85,33)$ dengan prosentase ketercapaian $(100 \%)$. Indikator keberhasilan target telah tercapai , penelitian di nyatakan berhasil dan dihentikan pada siklus II. Kesimpulan; pelaksanaan pendampingan dapat meningkatkan kompetensi guru kelas SDN Dondak dalam penyusunan RPP kurikulum 2013. Disarankan agar Kepala Sekolah lainnya melakukan penelitian sejenis dalam upaya peningkatan kompetensi guru, dan kepada guru mata pelajaran agar mampu menyusun RPP dengan baik dan benar.
\end{abstract}

Kata Kunci : Pendampingan $-R P P$

\section{PENDAHULUAN}

\section{Latar Belakang}

Proses pembelajaran yang baik dan benar harus diawali dengan penyusunan Rencana Pelakssanaan Pembelajaran (RPP). Rencana Pelaksanaan Pembelajaran yang baik dan benar harus terbaca dengan jelas oleh tenaga pendidik/guru yang lain karena RPP yang baik dan benar itu harus bisa dibaca oleh guru lain dan bisa dilaksanakan jika guru yang bersangkutan berhalangan. Disamping itu skenario pembelajaran harus jelas dan terinci sehingga proses pembelajaran berjalan dengan baik dimana peserta didik diberikan kesempatan untuk beraktifitas, berkreatifitas dan mampu menemukan ide-ide sesuai dengan pengalaman belajarnya. Suasana pembelajaran di kelas menjadi dinamis, inovasi, kreasi, demokrasi, dan semangat kekeluargaan antara peserta didik dengan peserta didik, peserta didik dengan guru serta ramah lingkungan.

Rencana Pelaksanaan Pembelajaran (RPP) adalah rencana kegiatan pembelajaran tatap muka untuk satu pertemuan atau lebih. 
RPP dikembangkan dari silabus untuk mengarahkan kegiatan pembelajaran peserta didik dalam upaya mencapai kompetensi dasar (KD). Setiap pendidik pada satuan pendidikan berkewajiban menyusun RPP secara lengkap dan sistematis agar pembelajaran berlangsung secara inteteraktif, inspiratif, menyenangkan, menantang, efisien, memotivasi peserta didik untuk berpartisipasi aktif, serta memberikan ruang yang cukup bagi prakarsa, kreativitas, dan kemandirian sesuai dengan bakat, minat, dan perkembangan fisik serta psikologis peserta didik. RPP disusun berdasarkan KD atau subtema yang dilaksanakan satu kali pertemuan atau lebih.

Di SDN Dondak mulai tahun ini kelas I sampai dengan kelas VI sudah melaksanakan kurikulum 2013. Pelaksanakan proses pembelajaran didahului dengan penyusunan RPP yang baik dan benar berdasarkan kurikulum 2013. Namun dalam kenyataannya tidak semua guru menyusun Rencana Pelaksanaan Pembelajaran (RPP) sesuai dengan Permen Mendikbud No. 22 Tahun 2016, tentang standar proses yang didalamnya terdapat petunjuk tentang tata cara penyusunan RPP yang baik dan benar sesuai dengan kurikulum 2013. Sebelum diadakan tindakan, peneliti telah mengobservasi tentang keberadaan RPP berdasarkan kurikulum 2013 yang dibuat oleh semua guru.

Faktor penyebabnya adalah: 1) guru belum pernah mendapatkan bimbingan secara khusus bagaimana menyusun RPP yang baik dan benar dari kepala sekolah, 2) setiap guru mengajukan RPP untuk disyahkan oleh kepala sekolah tidak pernah disalahkan dan langsung ditanda tangani, 3) guru sangat jarang mengikuti pendidikan dan pelatihan (Diklat) tentang penyusunan RPP yang baik dan benar, kalaupun ada yang pernah mengikuti kegiatannya kurang serius, di jadwalkan 5 (lima) hari kerja baru tiga hari sudah ditutup, 4) alasan klasik guru beralasan jumlah jam mengajarnya banyak sehingga tidak sempat untuk menyusun RPP, prinsipnya yang penting mengajar di kelas dengan berpedoman dengan buku paket siswa yang sudah disediakan oleh pihak sekolah dan oleh peserta didik itu sendiri.

Sebenarnya banyak solusi yang dapat dilakukan oleh kepala sekolah selaku peneliti, antara lain: 1) diadakan bimbingan/pendampingan khusus bagi guru sasaran, 2) diadakan bintek khusus penyusunan RPP yang baik dan benar, 3) di galakkan pelaksanaan Kelompok Kerja Guru (KKG), dan lain-lain. Dalam penelitian ini kepala sekolah memilih melakukan pendampingan bagi 6 (enam) guru sasaran melalui wadah KKG dalam upaya meningkatkan kompetensi guru menyusun RPP yang baik dan benar, semester dua tahun pelajaran 2018/2019 yang di pusatkan di SDN Dondak. Ada beberapa keunggulan pelaksanaan sistem pendampingan berbasis KKG yakni: 1) melatih keberanian guru untuk berpendapat terhadap sesama guru, 2) pekerjaan yang berat bisa menjadi ringan, 3) menambah nilai kekeluargaan, kebersamaan, dan jiwa saling menolong, 4) bisa mengemukakan ide, gagasan, serta etos kerja yang berkualitas, dan 5) bisa merubah mindset guru dalam perencanaan proses pembelajaran dan sistem penilaian. Berdasarkan beberapa keunggulan dari proses pendampingan berbasis KKG, peneliti meyakini rendahnya kompetensi guru dalam penyusunan RPP yang baik dan benar dapat diminimalkan dan bahkan mampu meningkatkan kualitas proses dan hasil belajar peserta didik di kelas senyatanya.

\section{Rumusan Masalah}

"Bagaimana

pendampingan berbasis KKG untuk meningkatkan kompetensi guru dalam penyusunan RPP yang baik dan benar semester dua tahun pelajaran 2018/2019 di SDN Dondak?"

\section{Tujuan Penelitian}

"Untuk mengetahui efektifitas pelaksanaan pendampingan secara klasikal dan individual berbasis KKG dalam upaya meningkatkan kompetensi guru dalam penyusunan RPP yang baik dan benar semester dua tahun pelajaran 2018/2019 di SDN Dondak." 


\section{Manfaat Penelitian}

1. Bagi guru SDN Dondak; bermanfaat dalam upaya penyusunan RPP yang baik dan benar, sehingga dapat diterapkan secara optimal dan terstruktur dalam proses pembelajaran di kelas sesuai dengan spesifikasi bidang studi/mata pelajaran yang menjadi tanggung jawabnya.

2. Bagi Kepala SDN Dondak; bermanfaat dalam upaya meningkatkan kompetensi guru dalam penyusunan RPP yang baik dan benar berdasarkan kurikulum 2013 (K.13), melalui kegiatan pendampingan berbasis KKG.

\section{KAJIAN PUSTAKA \\ Kerangka Teoritis \\ Kompetensi Guru}

Guru adalah pendidik profesional dengan tugas utama mendidik, mengajar, membimbing, mengarahkan, melatih, menilai, dan mengevaluasi peserta didik pada pendidikan anak usia dini jalur pendidikan formal, pendidikan dasar, dan menengah (Undang-Undang RI Nomor 14 Tahun 2005 Tentang Guru dan Dosen). Guru merupakan seseorang yang mempunyai tugas mulia untuk mendorong, membimbing dan memberi fasilitas belajar bagi siswa untuk mencapai tujuan. Guru mempunyai tanggung jawab untuk melihat segala sesuatu yang terjadi dalam kelas untuk membantu proses perkembangan siswa. Penyampaian materi pelajaran hanyalah merupakan salah satu dari berbagai kegiatan dalam belajar sebagai suatu proses yang dinamis dalam segala fase dan proses perkembangan siswa (Slameto, 2003: 97).

Kompetensi Guru; Kompetensi profesional guru menurut Sudjana (2002 : 1719) dapat dikelompokkan menjadi tiga bidang yaitu pedagogik, personal dan sosial. Kompetensi pedagogik menyangkut kemampuan intelektual seperti penguasaan mata pelajaran, pengetahuan menganai cara mengajar, pengetahuan mengenai belajar dan tingkah laku individu, pegetahuan tentang bimbingan penyuluhan, pengetahuan tentang administrasi kelas, pengetahuan tentang cara menilai hasil belajar, pengetahuan tentang kemasyarakatan serta pengetahuan umum lainnya.

Berdasarkan Peraturan Pemerintah Nomor 19 Tahun 2005 tentang Standar Nasional Pendidikan, guru harus memiliki kompetensi pedagogik, kepribadian, profesional, dan sosial (Depdiknas, 2005 : 24, $90-91)$.

1. Kompetensi pedagogik merupakan kemampuan yang berkenaan dengan pemahaman peserta didik dan pengelola pembelajaran yang mendidik dan dialogis. Secara substantif kompetensi ini mencakup kemampuan pemahaman terhadap peserta didik, perancangan dan pelaksanaan pembelajaran, evaluasi hasil belajar, dan pengembangan peserta didik untuk mengaktualisasikan berbagai potensi yang dimilikinya.

2. Kompetensi kepribadian merupakan kemampuan personal yang mencerminkan kepribadian yang mantap, arif, dewasa, dan berwibawa, menjadi teladan bagi peserta didik, dan berakhlak mulia.

3. Kompetensi profesional merupakan kemampuan yang berkenaan dengan penguasaan materi pembelajaran bidang studi secara luas dap mendalam yang mencakup penguasaan substansi isi materi kurikulum matapelajaran di sekolah dan substansi keilmuan yang menaungi materi kurikulum tersebut, serta menambah wawasan keilmuan sebagai guru.

4. Kompetensi sosial berkenaan dengan kemampuan pendidik sebagai bagian dari masyarakat untuk berkomunikasi dan bergaul secara efektif dengan peserta didik, sesama pendidik, tenaga kependidikan, orangtua/wali peserta didik, dan masyarakat sekitar.

Yang dimaksud dengan kompetensi guru dalam penelitian tindakan sekolah (PTS) ini adalah kemampuan 9 (sembilan) guru sasaran dalam penyusunan Rencana Pelaksanaan Pembelajaran (RPP) yang baik dan benar. Adapaun ciri-ciri RPP dikatakan baik 
dan benar adalah: 1) memuat aktifitas proses belajar mengajar yang akan dilaksanakan oleh guru dan menjadi pengalaman belajar bagi peserta didik, 2) langkah-langkah pembelajaran disusun secara sistematis agar tujuan pembelajaran dapat dicapai, 3) langkah-langkah pembelajaran disusun serinci mungkin, sehingga apabila RPP digunakan guru lain (misalnya, ketiga guru mata pelajaran tidak hadir) mudah dipahami dan tidak menimbulkan penafsiran ganda

\section{Pendampingan}

Pendampingan adalah Upaya terus menerus dan sistematis dalam mendampingi (menfasilitasi) individu, kelompok maupun komunitas dalam mengatasi permasalahan dan menyesuaikan diri dengan kesulitan hidup yang dialami sehingga mereka dapat mengatasi permasalahan tersebut dan mencapai perubahan hidup ke arah yang lebih baik. (Yayasan Pulih, 2011). Pendampingan merupakan proses interaksi timbal balik (tidak satu arah) antara individu/ kelompok/komunitas yang mendampingi dan individu/kelompok/komunitas yang didampingi yang bertujuan memotivasi dan mengorganisir individu/kelompok/komunitas dalam mengembangkan sumber daya dan potensi orang yang didampingi dan tidak menimbulkan ketergantungan terhadap orang yang mendampingi (mendorong kemandirian). (Yayasan Pulih, 2011). Pendampingan dapat dilakukan dalam berbagai bentuk maupun situasi dengan pendekatan yang beragam baik formal maupun non formal, individu, kelompok maupun komunitas.

Dalam wujudnya yang paling efektif, pendampingan adalah kemitraan pembelajaran yang melibatkan kerjasama dan peluang untuk menghadapi tantangan dan melakukan refleksi berkelanjutan oleh kedua belah pihak yang terlibat. Hubungan pendampingan bisa juga berupa kemitraan sejawat yang di dalamnya, posisi dan peran pendamping dan yang terdampingi bisa saja bertukar berdasarkan konteks tertentu.
Yang dimaksud dengan pendampingan dalam penelitian tindakan sekolah (PTS) ini adalah kepala SDN Dondak selaku peneliti membimbing /mendampingi terhadap 11 (sebelas) guru sasaran dalam penyusunan RPP yang baik dan benar. Dalam pelaksanaannya pendampingan dilakukan melalui 2 (dua) tahapan. Tahap I semua guru dikumpulkan untuk mendapatkan penjelasan teknik tata cara penyusunan RPP yang baik dan benar sesuai dengan bidang studi/mata pelajaran yang diampunya. Tahap II yaitu pendampingan individual, dimana peneliti mendampingi secara individu dalam kelompok kecil untuk menjelaskan lebih rinci tata cara menyusun RPP yang baik dan benar.

\section{KKG}

Trimo (2007: 12) Kelompok Kerja Guru yaitu suatu organisasi profesi guru yang bersifat struktural yang dibentuk oleh guru-guru di suatu wilayah atau gugus sekolah sebagai wahana untuk saling bertukaran pengalaman guna meningkatkan kemampuan guru dan memperbaiki kualitas pembelajaran. Menurut Buchari Zainun 1987 (dalam, Suryosubroto 2004: 1) ada lima faktor yang mendasari kegiatan manusia dalam organisasi yaitu:

a. Faktor spesialisasi dan pembagian kerja;

b. Faktor koordinasi;

c. Faktor tujuan;

d. Faktor prosedur kerja;

e. Faktor dinamika lingkungan.

Melalui KKG guru memiliki kesempatan dan berpotensi mendiskusikan penyelesaian permasalahan yang dihadapi di kelas. Trimo (2007: 12) menyatakan, "pembinaan melalui KKG memberikan kesempatan bagi guru yang lebih luas (dimungkinkan semua guru terlibat), dibanding bentuk pembinaan yang lain (harus menunggu kesempatan)".

Yang dimaksud dengan KKG dalam penelitian ini adalah 9 (sembilan) guru SDN Dondakyang menjadi sasaran dalam pelaksanaan pendampingan dalam penyusunan RPP berdasarkan Kurikulum 2013. Kegiatan nyata KKG SDN Dondak yaitu penyusunan 
Rencana Pelaksanaan Pembelajaran (RPP) yang dibimbing langsung oleh kepala sekolah selaku peneliti. Dalam kegiatan ini semua guru kelas dari kelas I sampai dengan guru kelas VI menyusun RPP secara individual dalam forum KKG. Kendala/kesulitan yang dialami oleh guru langsung diberikan bimbingan, perbaikan, dan penyempurnaan sesuai dengan situasi dan kondisi pada saat KKG yang diselenggarakan di SDN Dondak.

Secara umum kegiatan KKG dapat memberikan manfaat sebagai berikut:

a. Sebagai tempat pembahasan dan pemecahan masalah bagi para guru yang mengalami kesulitan dalam kegiatan pembelajaran.

Masalah-masalah yang dihadapi oleh guru dalam proses pembelajaran di kelas tentu beragam bentuk dan modelnya. Penganganan terhadap setiap persoalanpun untuk mencari jalan keluar jelas akan berbeda dengan persoalan lainnya. Dapat dipahami bahwa semua guru belum tentu berpengalaman seperti layaknya guru-guru senior yang mungkin saja memiliki lebih banyak teknik dan cara-cara dalam mengatasi persoalan terlebih-lebih persoalan belajar mengajar. Untuk itulah guru-guru baru atau guru lain yang memiliki persoalan yang menurutnya sulit dapat dipecahkan melalui KKG dengan cara berdiskusi dan berbagi pengalaman dengan guru lainnya.

b. Sebagai wadah kegiatan para guru yang tergabung dalam satu gugus yang ingin meningkatkan profesionalnya secara bersama-sama. Peningkatan profesional guru memang suatu keharusan, dan sekolah pada dasarnya mempunyai kewajiban dalam hal itu. Akan tetapi melalui KKG kewajiban sekolah dalam peningkatan kualitas guru dapat diwujudkan. Jadi sekolah tidak terlalu repot mengadakan berbagai macam pelatihan, cukup dengan mengutus gurunya mengikuti program KKG.

c. Sebagai tempat penyebaran informasi tentang pembaharuan pendidikan khususnya yang berkaitan dengan usaha peningkatan hasil belajar. Penigkatan hasil pembelajaran melalui pembaharuan pendidikan dapat diwujudkan melalui KKG. Caranya adalah menyerap informasi sebanyak-banyaknya tentang format-format dan strategi pembaharuan pendidikan yang kemudian dapat diaplikasikan atau dipraktekkan di sekolah masing-masing.

d. Sebagai pusat kegiatan praktek pembuatan alat peraga, penggunaan perpustakaan serta perolehan berbagai keterampilan mengajar maupun pengembangan administrasi kelas. Perbedaan materi ajar mengakibatkan adanya perbedaan alat peraga yang digunakan. Guru harus jeli menggunakan setiap alat peraga yang akan digunakan dalam PBM, sebab kalau tidak alat peraga bukanlah menambah efektivitas pembelajaran akan tetapi berpeluang menjadi sumber gangguan dalam pembelajaran. Disisi lain guru mungkin saja masih banyak yang tidak menggunakan alat peraga sebagai alat bantu belajar padalah hal itu sangat penting. Untuk itulah melalui KKG beberapa keterampilan dalam membuat alat peraga atau keterampilan lainnya dapat dipelajari. Mengenai hal ini Nadriansyah mengatakan: Melalui kelompok kerja yang dimaksud banyak kreativitas yang dapat dikembangkan, seperti merancang pengajaran, merancang alat peraga, merumuskan mekanisme KBM dan membuat rumusan tata cara menindak lanjuti hasil karya guru dan siswa.

e. Memberikan kesempatan kepada guru yang kreatif dan inovatif untuk berbagi pengetahuan, wawasan, kemampuan dan keterampilan profesional kepada sesama teman sejawat dan mendiskusikan untuk memperoleh sesuatu yang lebih baik dalam usaha meningkatkan mutu pengetahuan, wawasan, kemampuan dan keterampilan.

\section{Rencana Pelaksanaan Pembelajaran (RPP)}

RPP adalah singkatan dari Rencana Pelaksanaan Pembelajaran. Dalam pedoman umum pembelajaran untuk penerapan Kurikulum 2013 disebutkan bahwa rencana pelaksanaan pembelajaran (RPP) adalah 
rencana pembelajaran yang dikembangkan secara rinci dari suatu materi pokok atau tema tertentu yang mengacu pada silabus. RPP mencakup: (1) data sekolah, matapelajaran, dan kelas/semester; (2) materi pokok; (3) alokasi waktu; (4) tujuan pembelajaran, KD dan indikator pencapaian kompetensi; (5) materi pembelajaran; metode pembelajaran; (6) media, alat dan sumber belajar; (6) langkah-langkah kegiatan pembelajaran; dan (7) penilaian. Semua guru di setiap sekolah harus menyusun RPP untuk mata pelajaran kelas di mana guru tersebut mengajar (guru kelas dan guru mata pelajaran). Guru kelas adalah sebutan untuk guru yang mengajar kelas-kelas pada tingkat tertentu di Sekolah Dasar (SD). Sedangkan guru mata pelajaran adalah guru yang mengampu mata pelajaran tertentu pada kenjang SMP/MTs, SMA/MA, dan SMK/MAK.

\section{Prinsip-Prinsip Pengembangan RPP Menurut Kurikulum 2013}

Beberapa prinsip penting yang harus diperhatikan saat mengembangkan atau menyusun RPP adalah sebagai berikut.

1. RPP disusun oleh guru sebagai terjemahan dari ide kurikulum dan berdasarkan silabus yang telah dikembangkan di tingkat nasional ke dalam bentuk rancangan proses pembelajaran untuk direalisasikan dalam pembelajaran. Jadi dalam hal ini guru harus mampu menterjemahkan ide-ide yang dimuat dalam Kurikulum 2013. Penterjemahan ide-ide didasarkan pada silabus yang telah disiapkan oleh pemerintah pusat dalam hal ini departemen pendidikan dan kebudayaan. Kemampuan menterjemahkan ide akan terlihat saat guru mengembangkan RPP dan menyesuaikan apa yang dinyatakan dalam silabus dengan kondisi di satuan pendidikan baik kemampuan awal peserta didik, minat, motivasi belajar, bakat, potensi, kemampuan sosial, emosi, gaya belajar, kebutuhan khusus, kecepatan belajar, latar belakang budaya, norma, nilai, dan/atau lingkungan peserta didik.
2. RPP yang dibuat selalu mengedepankan perencanaan pembelajaran yang nantinya dalam proses belajar mengajar akan mendorong partisipasi aktif siswa. RPP yang dibuat tidak boleh menyimpang dari tujuan Kurikulum 2013 yaitu untuk menghasilkan siswa sehingga menjadi manusia yang mandiri dan tak berhenti belajar (pebelajar sepanjang hayat/lifelong learner), proses pembelajaran yang berpusat pada siswa (student centered) sehingga dapat mengembangkan motivasi, minat, rasa ingin tahu (curiousity), kreativitas, inisiatif, inspirasi, kemandirian, semangat belajar, keterampilan belajar dan kebiasaan belajar.

3. Pengembangan RPP yang baik akan mengedepankan proses pembelajaran yang mengembangkan budaya membaca dan menulis pada diri peserta didik. Proses pembelajaran dalam RPP dirancang untuk mengembangkan kegemaran membaca, pemahaman beragam bacaan, dan berekspresi dalam berbagai bentuk tulisan.

4. Di dalam RPP terdapat cara-cara dan langkah-langkah yang dapat dilakukan oleh guru untuk memberikan umpan balik (feedback) dan tindak lanjut (follow up). RPP memuat rancangan program pemberian umpan balik positif (positive feedback), penguatan (reinforcement), pengayaan (enrichment), dan remedi. Pemberian pembelajaran remedi harus dilakukan guru setiap saat setelah suatu ulangan atau ujian dilakukan, hasilnya dianalisis, dan kelemahan setiap peserta didik dapat teridentifikasi. Pemberian pembelajaran diberikan sesuai dengan kelemahan peserta didik.

5. Perancangan RPP memperhatikan keterkaitan dan keterpaduan antara materimateri pembelajaran yang satu dengan materi pembelajaran yang lainnya. RPP harus sedemikian rupa sehingga keterkaitan dan keterpaduan antara KI dan KD, materi pembelajaran, kegiatan pembelajaran, penilaian, dan sumber belajar menjadi satu kesatuan utuh berbentuk pengalaman belajar 
yang bermakna bagi siswa. RPP disusun dengan mengakomodasikan pembelajaran tematik, keterpaduan lintas matapelajaran untuk sikap dan keterampilan, dan keragaman budaya.

6. Menerapkan teknologi informasi dan komunikasi. RPP disusun dengan mempertimbangkan penerapan teknologi informasi dan komunikasi secara terintegrasi, sistematis, dan efektif sesuai dengan situasi dan kondisi.

\section{Komponen dan Sistematika RPP}

RPP pada Kurikulum 2013 paling sedikit memuat: (i) tujuan pembelajaran, (ii) materi pembelajaran, (iii) metode pembelajaran, (iv) sumber belajar, dan (v) penilaian.

\section{Kerangka Konseptual}

Variabel harapan dalam penilaian ini adalah meningkatnya kompetensi 6 (enam) guru sasaran dalam penyusunan RPP yang baik dan benar, sedangkan variabel tindakan dalam penelitian ini adalah melaksanakan pendampingan secara klasikal (kelompok besar) dan pendampingan individual (kelompok kecil/perorangan) berbasis KKG.

\section{Hipotesis Tindakan}

"jika pendampingan dilaksanakan dengan baik, maka kompetensi guru dalam penyusunan RPP yang baik dan benar bagi guru sasaran SDN Dondak semester dua tahun pelajaran 2018/2019 dapat di tingkatkan"

\section{PROSEDUR PENELITIAN}

\section{Jenis Tindakan}

Setting Penelitian

Penelitian Tindakan Sekolah (PTS) ini dilaksanakan di SDN Dondakyang pelaksanaannya melalui kegiatan pendampingan berbasis KKG bagi 9 (sembilan) guru sasaran dalam penyusunan RPP yang baik dan benar yang dilaksanakan dalam forum KKG sekolah.

\section{Perencanaan Tindakan}

\section{Jenis tindakan yang dilakukan}

1. Kepala sekolah menginformasikan hasil pantauan, supervisi administrasi terhadap 6 (enam) guru sasaran bahwa guru-guru dimaksud masih belum mampu/mengalami kendala/hambatan-hambatan dalam penyusunan RPP yang baik dan benar.

2. Kepala sekolah menyampaikan perlunya diadakan pendampingan berbasis KKG bagi guru sasaran dalam penyusunan RPP yang baik dan benar

3. Kepala Sekolah menyampaikan materi pendampingan sesuai dengan skenario pelaksanaan pendampingan berbasis KKG yang dirinci sebagai berikut:

- Pendampingan klasikal. Pada kegiatan ini peneliti menyampaikan materi secara klasikal dilanjutkan dengan kegiatan kerja kelompok (diskusi kelompok)

- Pendampingan individual. Pada kegiatan ini peneliti mengamati kegiatan kelompok dan mendampingi secara individual terutama bagi peserta pendampingan yang mengalami kesulitan.

Untuk mendapatkan gambaran riil tentang skenario pelaksanaan tindakan pada kegiatan pendampingan berbasis KKG ini dapat di gambarkan sebagai berikut:

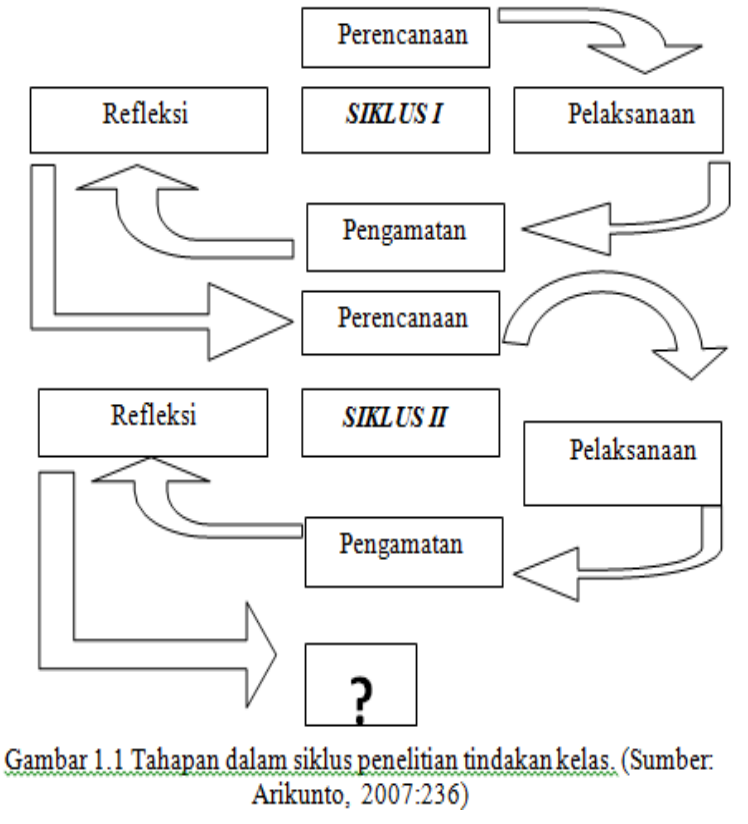

Pelaksanaan Tindakan

Adapun jenis instrumen yang digunakan dalam penelitian ini sebagai berikut: 
1. Instrumen pengamatan/observasi kepala sekolah dilakukan oleh observer.

2. Instrumen pengamatan/observasi guru peserta pendampingan dilakukan oleh peneliti (kepala sekolah)

3. Instrumen penilaian hasil kerja individual dalam penyusunan RPP yang baik dan benar dilakukan oleh peneliti, ini sekaligus merupakan tolak ukur berhasil tidaknya dalam penyusunan RPP melalui pendampingan berbasis KKG sesuai dengan indikator keberhasilan yang telah di tetapkan.

\section{Evaluasi dan Refleksi Tindakan}

Adapun kegiatan riilnya adalah: 1) membandingkan hasil pengamatan pelaksanaan kerja kelompok/diskusi yang difokuskan kegiatan penyusunan RPP yang baik dan benar berdasarkan kurikulum 2013, 2) membandingkan hasil kerja individual dari 6 (enam) guru sasaran dalam penyusunan RPP dengan indikator keberhasilan yang telah ditetapkan.

\section{Siklus Tindakan}

Dalam penelitian ini di rencanakan sebanyak 2 (duaa) siklus, masing-masing siklus 1 (satu) kali pertemuan dengan agenda 2 (dua) kegiatan secara terpadu yaitu pendampingan klasikal/kelompok besar dan pendampingan individual/kelompok kecil. Kegiatan masingmasing siklus terdiri dari 4 (empat) tahapan yaitu perencanaan, pelaksanaan, observasi, dan refleksi. Untuk mendapatkan gambaran secara rinci kegiatan masing-masing tahapan dapat di jelaskan sebagai berikut:

\section{SIKLUS I}

\section{Tahap I : Perencanaan Tindakan}

1.1. Menyusun materi pendampingan

1.2. Menetapkan scenario dan langkahlangkah pendampingan yang tertuang dalam Rencana Pelaksanaan pendampingan (RPP)

1.3. Menyusun instrument observasi kepala sekolah dan observasi guru
1.4. Menentukan jadwal pendampingan

1.5. Menyusun pedoman analisa data hasil observasi dan tugas individu.

\section{Tahap II. Pelaksanaan Tindakan}

Pada kegiatan pendampingan secara berkelompok yang kegiatannya adalah :

2.1. Menyampaikan materi tentang tata cara penyusunan RPP yang baik dan benar.

2.2. Melaksanakan diskusi kelompok kecil dalam penyusunan RPP.

2.3. Memberikan bimbingan secara berkelompok/perorangan.

2.4. Memberikan solusi terhadap permasalahan yang dihadapi oleh guru

2.5. Memberikan penguatan/reward

2.6. Memberikan tugas individual.

Pada kegiatan pendampingan individual yang dilakukan secara bergiliran, dengan cara peneliti mendekati guru satu persatu dalam kelompok untuk membimbing secara individual agar permasalahan-ppermasalahan dapat dipecahkan dengan baik dan benar.

\section{Tahap III. Observasi/pengumpulan Data}

3.1. Pengamatan terhadap aktifitas guru peserta pendampingan

3.2. Pengamatan terhadap kinerja guru dalam penyusunan RPP yang baik dan benar.

3.3. Menilai hasil kerja guru secara individual Tahap IV. Refleksi

4.1. Renungan atas data hasil observasi dan hasil kerja secara individual.

4.2. Pengolahan data hasil penelitian dan mencocokkan dengan indikator keberhasilan.

4.3. Rencana perbaikan dan penyempurnaan

4.4. Memberikan penguatan atas hasil yang diperolehnya.

4.5. Rencana tindak lanjut.

SIKLUS II

Jenis kegiatan pada siklus II ini pada dasarnya sama dengan siklus I, bedanya hanya terjadi perbaikan/penyempurnaan dalam pelaksanaannya.

\section{Indikator Keberhasilan}

Pelaksanaan

berkelompok berbasis

klasikal/kelompok besar pendampingan

KKG secara

maupun secara 
individual/kelompok kecil dinyatakan telah berhasil jika:

1. Hasil observasi kepala sekolah maupun observasi guru peserta pendampingan telah mencapai skor rata-rata $\geq 4,0$ (Kategori baik).

2. Hasil kerja secara individual penyusunan RPP yang baik dan benar berdasarkan kurikulum 2013 dinyatakan telah berhasil jika mencapai $\geq 85 \%$ dengan nilai rata-rata $\geq 70,00$ (Kategori Baik).

\section{HASIL PENELITIAN DAN PEMBAHASAN} Hasil Penelitian

Deskripsi Siklus I

Tahap Perencanaan

Pada tahapan ini peneliti melakukan: 1) menyusun materi pendampingan, 2) menetapkan skenario dan langkah-langkah pendampingan yang tertuang dalam Rencana Pelaksanaan Pendampingan (RPP), 3) menyusun instrumen observasi kepala sekolah dan instrumen observasi guru, 4) menentukan jadwal kegiatan pendampingan, 5) menyusun pedoman analisis data

\section{Tahap Pelaksanaan}

Pada tahapan ini peneliti melakukan pendampingan secara klasikal maupun pendampingan secara individual, dengan rincian kegiatan sebagai berikut:

- Pendampingan klasikal/kelompok; 1) menyampaikan materi tentang tata cara penyusunan RPP yang baik dan benar, 2) melaksanakan diskusi kelompok kecil dalam penyusunan RPP, 3) memberikan bimbingan secara berkelompok, 4) memberikan solusi terhadap permasalahan yang dihadapi oleh guru, 5) memberikan penguatan/reward, dan 6) memberikan tugas individual.

- Pendampingan individual, jenis kegiatannya adalah; 1) pada saat guru bekerja dalam kelompok/diskusi kelompok peneliti membimbing guru yang mengalami kesulitan dalam penyusunan RPP secara kelompok kecil/perorangan, 2) memberikan solusi/pemecahan terhadap kesulitan yang dirasakan secara individual, 3) kegiatan seterusnya sampai ke 6 (enam) guru peserta pendampingan mendapatkan giliran pendampingan secara individual

\section{Tahap Observasi}

Pada tahapan ini, hasil observasi kepala sekolah memperoleh skor rata-rata sebesar 3,40, observasi guru memperoleh skor rata-rata sebesra 3,33, dan Nilai Individual hasil penyusunan RPP berdasarkan kurikulum 2013 memperoleh nilai rata-rata sebesar 67,33

\section{Tahap Refleksi}

Pada tahapan ini peneliti merenung atas perolehan data hasil observasi kepala sekolah, observasi guru, dan nilai individual hasil penyusunan RPP yang baik dan benar. Selanjutnya peneliti mengolah data dan hasilnya di cocokkan dengan indikator keberhasilan dengan rincian sebagai berikut: Hasil Observasi Kepala Sekolah $(3,40)$, Hasil Observasi Guru (3,33), Rata-rata Nilai Individual $(67,33)$

Karena perolehan hasil masih dibawah indikator keberhasilan yang direncanakan, maka pada siklus berikutnya akan diadakan perbaikan dan penyempurnaan dari serangkaian kegiatan pendampingan secara klasikal maupun secara individual, namun demikian peneliti tetap memberikan penguatan atas hasil yang diperolehnya dan penelitian dilanjutkan pada siklus II dengan mengoptimalkan semua jenis tindakan dalam pendampingan sehingga di peroleh hasil yang memuaskan.

\section{Deskripsi Siklus II}

\section{Tahap Perencanaan}

Tahapan perencanaan pada siklus II jenis kegiatannya masih sama dengan siklus I, bedanya pada siklus II ini lebih memfokuskan perbaikan/penyempurnaan dalam proses pendampingan klasikal maupun pendampingan individual, yang jenis kegiatannya adalah: 1) menyempurnakan materi pendampingan, 2) menetapkan skenario pendampingan, 3) menetapkan instrumen observasi kepala sekolah maupun observasi guru, 4) menetapkan jadwal kegiatan pendampingan, 5) menyusun pedoman analisis data hasil observasi dan tugaas individu Tahap Pelaksanaan 
- Pendampingan klasikal/kelompok; 1)menyampaikan/merefleksi hasil perolehan data pada siklus I, 2) menjelaskan ulang tata cara penyusunan RPP yang baik dan benar secara lebih rinci, 3) perbaikan RPP secara berkelompok/diskusi kelompok, memberikan refleksi terhadap hasil kerja kelompok yang mengalami kendala, 5) memberikan penghargaan/reward dan 6) memberikan tugas individual.

- Pendampingan individual/kelompok kecil; 1) pada saat proses kerjasama dalam kelompok, peneliti mengamati/mencermati hasil kerja secara individual, 2) memberikan bimbingan/merefleksi terhadap hasil kerja individual yang masih mengalami kendala, 3) begitu seterusnya sampai semua guru peserta pendampingan mendapatkan pendampingan secara individual.

\section{Tahap Observasi/Pengumpulan Data}

Pada tahapan ini, hasil observasi kepala sekolah memperoleh skor rata-rata sebesar 4,40, observasi guru memperoleh skor rata-rata sebesra 4,50, dan Nilai Individual hasil penyusunan RPP berdasarkan kurikulum 2013 memperoleh nilai rata-rata sebesar 85,33

\section{Tahap Refleksi}

Pada tahapan ini peneliti merenung atas perolehan data hasil observasi kepala sekolah, observasi guru, dan nilai individual hasil penyusunan RPP yang baik dan benar. Kemudian di olah engan menggunakan rumus yang telah ditetapkan. Hasil perolehan data di cocokkan dengan indikator keberhasilan dengan perolehan data sebagai berikut: Hasil Observasi Kepala Sekolah $(4,40)$, Hasil Observasi Guru $(4,50)$, Rata-rata Nilai Individual $(85,33)$

Karena perolehan hasil siklus II sudah melebihi indikator keberhasilan, maka tidak perlu ada perbaikan/penyempurnaan dalam penyusunan RPP yang baik dan benar, selanjutnya peneliti memberikan penghargaan/reward kepada semua guru peserta pendampingan karena dari 6 (enam) guru sasaran $100 \%$ sudah memperoleh nilai rata-rata $\geq 70,00$. Penelitian dinayatakan berhasil dan tindakan dihentikan pada siklus II.

\section{Pembahasan \\ SIKLUS I \\ Tahap Perencanaan}

Ada beberapa kendala yang dihadapi dalam tahapan ini, diantaranya dalam penyusunan materi pendampingan, menetapkan skenario dan langkah-langkah pendampingan, penyusunan instrumen observasi kepala sekolah dan instrumen observasi guru, tetapi setelah mendapat solusi dan petunjuk dari pembimbing akhirnya kegiatan pada tahapan ini dapat dilaksanakan dengan baik dan lancar.

\section{Tahap Pelaksanaan}

Kegiatan nyata dalam pelaksanaan pendampingan dapat dijabarkan sebagai berikut: pada saat menyampaikan materi tentang tata cara penyusunan RPP yang baik dan benar mengalami kendala yang disebabkan peneliti masih kekurangan sumber/buku literatur, sehingga berdampak tertundanya dalam penyusunan, solusi yang dilakukan peneliti mencari beberapa buku literatur terkait dengan tata cara penyusunan RPP termasuk mencari di internet, akhirnya materi pendampingan dapat tersusun dengan baik.

Dalam pelaksanaan bimbingan pada saat peserta pendampingan melakukan diskusi/kerjasama dalam kelompok, peneliti berkeliling memberikan bimbingan dan solusi terhadap peserta yang mengalami kesulitan. Pada kegiatan ini peneliti tidak mengalami hambatan/permasalahan artinya berjalan sesuai dengan rencana.

\section{Tahap Observasi/Pengumpulan Data}

Hasil perolehan skor/nilai selama pendampingan pada siklus I peneliti memperoleh skor rata-rata $(3,40)$ dari indikator keberhasilan yang direncanakan yaitu $\geq 4,0$. Ini artinya peneliti masih belum berhasil membimbing 9 (sembilan) guru peserta pendampingan. Perolehan skor rata-rata aktifitas peserta pendampingan pada siklus I yaitu $(3,33)$ dari indikator keberhasilan $(\geq 4,0)$. Perolehan nilai rata-rata hasil kerja guru dalam penyusunan RPP yang baik dan benar secara individual memperoleh rata-rata $(67,33)$ dari indikator keberhasilan $\geq 70,0$ (kategori baik). 


\section{Tahap Refleksi}

Perolehan skor rata-rata hasil observasi kepala sekolah selama proses pendampingan baru memperoleh skor rata-rata $(3,40)$, sementara perolehan hasil observasi peserta pendampingan sebagai aktifitas peserta selama pendampingan baru memperoleh skor rata-rata $(3,33)$, dan nilai rata-rata hasil penyusunan RPP yang baik dan benar baru mencapai nilai ratarata $(67,33)$.

\section{SIKLUS II}

\section{Tahap Perencanaan}

Kesalahan-kesalahan yang terjadi pada siklus I sudah diperbaiki pada siklus II, sehingga pada tahapan ini peneliti bisa melakukan dengan baik. Kegiatan pada tahap perencanaan ini meliputi; 1) penyempurnaan penyusunan materi pendampingan, 2) perbaikan skenario/strategi/langkah-langkah

pendampingan yang mengarah kepada peserta aktif, 3) menetapkan instrumen observasi kepala sekolah dan instrumen observasi guru, 4) menentukan jadwal kegiatan dan menetapkan pedoman analisa data hasil observasi dan hasil kerja individual.

\section{Tahap Pelaksanaan}

Pada tahapan ini, peneliti terlebih dahulu melakukan refleksi atas capaian hasil yang diperoleh pada siklus I. Kendala-kendala dan permasalahan yang terjadi dibahas sampai semua peserta pendampingan memahami dan menyadari akan kekurangan, kesalahan dan halhal yang bersifat krusial dapat dipecahkan pada saat kegiatan refleksi.

\section{Tahap Observasi}

Pada siklus II perolehan skor rata-rata hasil observasi kepala sekolah adalah $(4,40)$ dari indikator keberhasilan $\geq 4,00$, ini artinya menunjukkan peningkatan yang sangat signifikan bila dibandingkan dengan perolehan hasil pada siklus I. Skor rata-rata hasil observasi guru yaitu aktifitas selama pendampingan dalam forum KKG memperoleh skor rata-rata $(4,50)$ dari indikator keberhasilan $\geq 4,00$. Dari hasil ini nampak nyata bahwa aktifitas peserta pendampingan pada siklus II mengalami peningkatan yang sangat tajam karena sudah mampu melampaui indikator keberhasilan yang telah ditetapkan. Nilai ratarata hasil kerja individual dalam penyusunan RPP yang baik dan benar yakni $(85,33)$ dari indikator keberhasilan $(\geq 70,00)$.

\section{Tahap Refleksi}

Berdasarkan hasil akhir perolehan skor rata-rata observasi kepala sekolah dan observasi guru serta hasil kerja individual penyusunan RPP yang baik dan benar semuanya telah melampaui indikator keberhasilan. Karena semua indikator keberhasilan telah tercapai maka penelitian tindakan sekolah dihentikan pada siklus II dan dinyatakan berhasil memotivasi guru untuk lebih bergairah dan lebih bersemangat dalam upaya penyusunan RPP yang baik dan benar. Penelitian Tindakan Sekolah dengan judul "Upaya Meningkatkan Kompetensi guru kelas dalam penyusunan Rencana Pelaksanaan Pembelajaran (RPP) Berdasarkan Kurikulum 2013 Melalui Pendampingan Berbasis KKG di SDN Dondak Semester dua Tahun pelajaran 2018/2019", dinyatakan "BERHASIL"

\section{KESIMPULAN DAN SARAN}

\section{Kesimpulan}

Perolehan data selama penelitian dapat dipaparkan sebagai berikut:

\begin{tabular}{|c|c|c|c|c|c|}
\hline \multirow{2}{*}{ Jenis Kegitan } & \multirow{2}{*}{$\begin{array}{l}\text { Indikator } \\
\text { Keberhasilan }\end{array}$} & \multicolumn{2}{|c|}{ Perolehan } & \multirow{2}{*}{ Peningkatan } & \multirow{2}{*}{ Ket } \\
\hline & & Siklus I & Siklus II & & \\
\hline $\begin{array}{l}\text { Hasil Observasi } \\
\text { Kepala Sekolah }\end{array}$ & $\geq 4,00$ & 3,40 & 4,40 & 1,00 & luntas \\
\hline Hasil Observasi Guru & $\geq 4,00$ & 3,33 & 4,50 & 1,17 & Tuntas \\
\hline Hasil Kerja Individual & $\geq 70,00$ & 67,33 & 85,33 & 18,00 & Tuntas \\
\hline
\end{tabular}

Pelaksanaan pendampingan berbasis KKG sangat efektif untuk meningkatkan kompetensi guru dalam penyusunan RPP yang baik dan benar bagi guru sasaran 9 (sembilan) guru SDN Dondak dalam penyusunan RPP yang baik dan benar. Hal ini dibuktikan meningkatnya perolehan hasil observasi dan hasil kerja individual dari siklus I ke siklus II. Penelitian tindakan sekolah (PTS) ini 
dinyatakan berhasil dan dihentikan pada siklus II.

\section{Saran}

Disarankan kepada rekan kepala sekolah lain untuk melakukan pendampingan dengan semua guru mata pelajaran dibawah binaan pada sekolah masing-masing dalam upaya meningkatkan kompetensinya khususnya dalam penyusunan RPP yang baik dan benar yang bisa diterapkan dalam proses pembelajaran di kelas senyatanya. Dampak yang diharapkan yaitu meningkatnya kualitas/mutu peserta didik di sekolah binaan melalui proses pembelajaran yang dilandasi dengan penyusunan RPP yang baik dan benar.

Kepada seluruh guru SDN Dondak disarankan untuk membiasakan melakukan musyawarah bersama dalam forum KKG mata pelajaran yang diampunya, khususnya dalam penyusunan RPP berdasarkan kurikulum 2013, sehingga berdampak meningkatnya kompetensi guru dalam proses pembelajaran di kelas senyatanya dan pada gilirannya prestasi belajar peserta didik dapat ditingkatkan.

\section{DAFTAR PUSTAKA}

Irwan sahaja , 2017, Pengertian Kelompok Kerja Guru, dalam http://irwansahaja.blogspot.co.id/2014/ 08/pengertian-kelompok-kerja-gurukkg.html, diakses tanggal 8 Februari 2017, pukul 12.30 Wita

Kementrian Pendidikan Nasional, 2010, Kepemimpinan Pembelajaran, Dirjen PMPTK

Keputusan Mentri Pendidikan Nasional No. 16 Tahun 2007, Standar Kualifikasi Akademik dan Kompetensi Guru.

Nana Sujana, 2009, Pendidikan Tingkat KePenelitian Konsep Dan Aplikasinya Bagi Peneliti Sekolah, Jakarta: LPP Bina Mitra.

Purnadi Pungki, M.W., 2009, KompetensiFaktor Kunci Keberhasilan, dalam http://vibizconsulting.com. Diakses tanggal 11 Juli 2016 pukul 19.35 wita

Peraturan Pemerintah No. 19 tahun 2005 tentang Standar Nasional Pendidikan
Suharjono, 2009, Melaksanakan Sekolah Sebagai Kegiatan Penelitian Tindakan Sekolah Sebagai Kegiatan Pengembangan Profesi Penelitia Sekolah, Jakarta: Bumi Aksara.

Suharjono, 2012, Publikasi Ilmiah Dalam Kegiatan Pengembangan Keprofesian Berkelanjutan Bagi Guru, Jakarta: Cakrawala Indonesia.

Undang-Undang Republik Indonesia, No. 14 Tahun 2005 , Guru dan Dosen Daftar Pustaka

Winsolu, 2009, Pengertian Kompetensi, dalam http://my.opera.com/winsolu/blog/penge rtian-kompetensi Diakses tanggal 11 Juli 2016 pukul 19.35 wita 2017, Definisi Pendampingan, dalam https://kamuspsikososial.wordpress.com Itag/definisi-pendampingan/, diakses tanggal 7 Februari 2017 Pukul 21.07 Wita

2017, Pengertian Pendampingan, dalam http://www.bintan-

s.web.id/2010/12/pengertianpendampingan.html, diakses tanggal 7 Februari 2017 Pukul 21.15 Wita . 2017, Kompetensi Guru, dalam https://karyono1993.wordpress.com/thes is/kompetensi-gurul, diakses tanggal 9

Februari 2017 Pukul 09.00 wita , 2017, Pengertian Kompetensi dan Kompetensi Guru, dalam https://mujibjee.wordpress.com/2010/01 111/pengertian-kompetensi-dankompetensi-gurul, di akses 13 Februari 2017 Pukul 15.00 wita , 2017, RPP dan Perencanaan Pembelajaran Kurikulum 2013 dalam http://penelitiantindakankelas.blogspot. co.id/2013/11/perancangan-RPPKurikulum-2013.html, , diakses 18 Februari 2017 Pukul 12.35 Wita 